8-2002

\title{
Agricultural Product Loads and Warehouse Failures
}

Norbert J. Delatte

Cleveland State University, n.delatte@csuohio.edu

Follow this and additional works at: https://engagedscholarship.csuohio.edu/encee_facpub

Part of the Construction Engineering and Management Commons, and the Structural Engineering Commons

How does access to this work benefit you? Let us know!

\section{Publisher's Statement}

(c) ASCE

\section{Original Citation}

Delatte, N. (2002). "Agricultural Product Loads and Warehouse Failures." J.Perform.Constr.Facil., 16(3), 116-123.

This Article is brought to you for free and open access by the Civil and Environmental Engineering at EngagedScholarship@CSU. It has been accepted for inclusion in Civil and Environmental Engineering Faculty Publications by an authorized administrator of EngagedScholarship@CSU. For more information, please contact library.es@csuohio.edu. 


\title{
Agricultural Product Loads and Warehouse Failures
}

\author{
Norbert Delatte, M.ASCE${ }^{1}$
}

\begin{abstract}
Two manufactured metal building warehouses loaded with agricultural products failed in service. Inspection revealed considerable damage to the structure and the foundation. The building owner filed suit against the building supplier, the building erector, and the soils testing laboratory whose engineer had designed the foundation. The agricultural product imposed substantial outward lateral pressures on the walls of the structures. Review of the available design documents indicated that these loads had not been accounted for in design. A structural analysis revealed that elements of the structure were underdesigned for the agricultural product loads. In addition, the foundation did not have any slab reinforcement to resist the loads. To prevent similar failures, these loads must be accounted for in design. The steel structure design and foundation design were both deficient. A contributing factor was the lack of communication between the designer of the structure and the designer of the foundation, due to the lack of a single engineer of record to take responsibility for the buildings.
\end{abstract}

CE Database keywords: Structural failure; Litigation; Loads; Building design.

\section{Introduction}

Two manufactured metal buildings were purchased and erected for use as agricultural product storage warehouses. The product stored was cottonseed. The cottonseed was separated from the seed in a gin building adjacent to each warehouse, and then blown in for storage until it could be sold. The blower loaded the warehouses from one end, with the product removed through a door at the other end. The warehouses were intended to be fully loaded with the product. Once the pile of cottonseed reached the peak of the roof, an auger built into the roof was used to move it toward the door. The warehouse storage capability would allow the owner to store cottonseed until it could be sold at a higher price. The two warehouses were located in towns about $32 \mathrm{~km}(20 \mathrm{mi})$ apart.

For two years, the warehouses were only partially loaded. During the third season, the warehouses were loaded to the roof, and workers outside of the building observed outward bulging of the warehouse walls. Once the product was removed, the concrete floor slabs were found to be badly cracked. The structure was also damaged, with evidence of permanent deformation. Much of the outward bulging disappeared when the cottonseed was removed, but the distortion in the metal walls remained.

The owner filed suit against the metal building manufacturer, the erector, and the soil testing company that had prepared the foundation design. The owner's attorney retained the author as an expert witness.

\section{Inspection}

The author first inspected the two warehouses in August 1999. Both warehouses were empty. Each warehouse was 24.4 by 42.7 $\mathrm{m}(80$ by $140 \mathrm{ft})$ in plan. The side warehouse walls were just over $7.26 \mathrm{~m}$ (23 ft $10 \mathrm{in}$.) high, with the roof rising at a $45^{\circ}$ angle to a peak $18.3 \mathrm{~m}(60 \mathrm{ft})$ high. One of the warehouses is shown in Fig. 1 . The auger, intended to move the product from the loading end to the door, was at the peak of the roof.

The structural configuration of both warehouses was identical. The interior framing of one of the warehouses is shown in Fig. 2. Six gable frames are spaced at $6.1 \mathrm{~m}(20 \mathrm{ft})$ intervals. Between the gable frames are interior soldier columns. The tops of the interior soldier columns are restrained by steel angle bracing leading back to the gable frames. Each of the pair of braces at the top of each column has two parts, with bolts attaching them to other parts of the structural secondary framing. The first and last bays have $\mathrm{x}$-bracing for longitudinal stability of the structure. Each end wall had seven columns.

These structures were purchased with an interior liner, so the inner and outer walls of the building were separated by purlins. Flange braces were provided to brace the side and end wall columns against lateral-torsional buckling and had been attached to the inner liner panel with self-tapping screws.

The inspection of warehouse 1 revealed the following damage:

1. On the right side of the far end of the warehouse (loading end), the top of the wall had been torn outward. This is shown in Fig. 3. From inside the warehouse, the sky was visible through the gap.

2. The interior liner of the wall at the far end of the warehouse showed signs of permanent distortion (wrinkling) due to outward bulging.

3. A large number of the flange braces on the end walls had been torn away from the interior liner and were hanging down. This is illustrated in Fig. 4. The cotton lint pattern in this figure also provided an indication of how high the seed was piled at the end wall. Some flange braces along the side walls were also torn away, as shown in Fig. 2. More flange braces were torn away lower on the walls than higher up. 


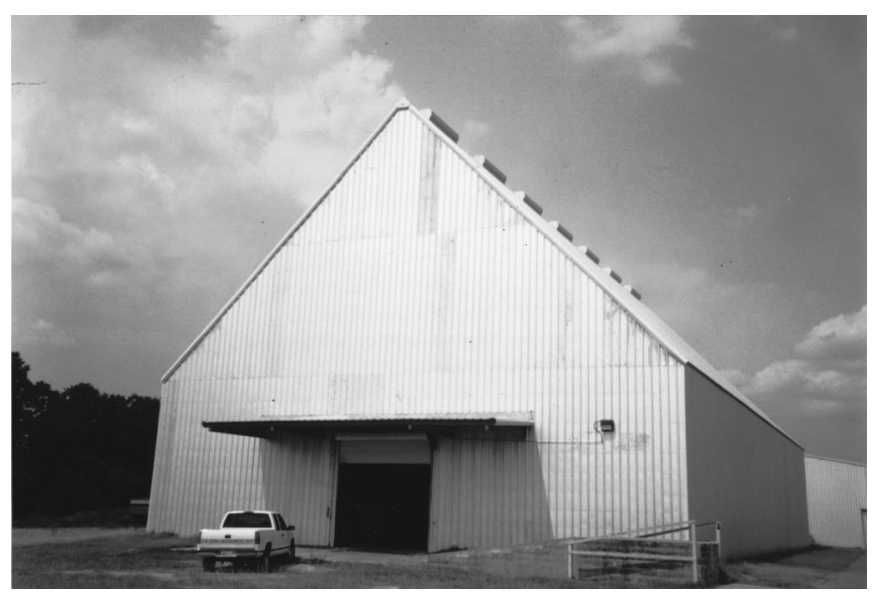

Fig. 1. Exterior view of warehouse

4. The concrete slab foundation was badly cracked. Cracks ran near the bases of the side wall columns nearest to the end wall. Cracks on the right-hand side near the end wall are shown in Fig. 5. Cracks also ran parallel to the end wall. Cracks were approximately $3-6 \mathrm{~mm}$ (1/8 to $1 / 4 \mathrm{in}$.) wide. Some cracks ran about $100 \mathrm{~mm}$ (4 in.) from the inner column flange, and some were about $1 \mathrm{~m}(3 \mathrm{ft})$ from the inner column flange.

5. Overall, the greatest damage was closest to the end wall. The door ends had almost no damage.

The inspection of warehouse 2 revealed the following damage:

1. On the left side of the far end of the warehouse (loading end), a brace holding back the top of an interior soldier column had been torn away. This is shown in Fig. 6 .

2. The wall at the far end of the warehouse showed signs of permanent distortion, similar to warehouse 1 .

3. Some flange braces on the end wall and along the side walls had been torn away, similar to warehouse 1 .

4. The concrete slab foundation cracking in warehouse 2 was worse than in warehouse 1 . A large crack about $25 \mathrm{~mm}$ (1 in.) wide, shown in Fig. 7, ran parallel to the end wall. The height differential across the crack was approximately $3 \mathrm{~mm}$ (1/8 in.), with the side next to the wall lower. On the left side wall, the three columns closest to the end wall had D-shaped cracks around them, and a large crack ran parallel to the wall just over $1 \mathrm{~m}(3 \mathrm{ft})$ from the wall.

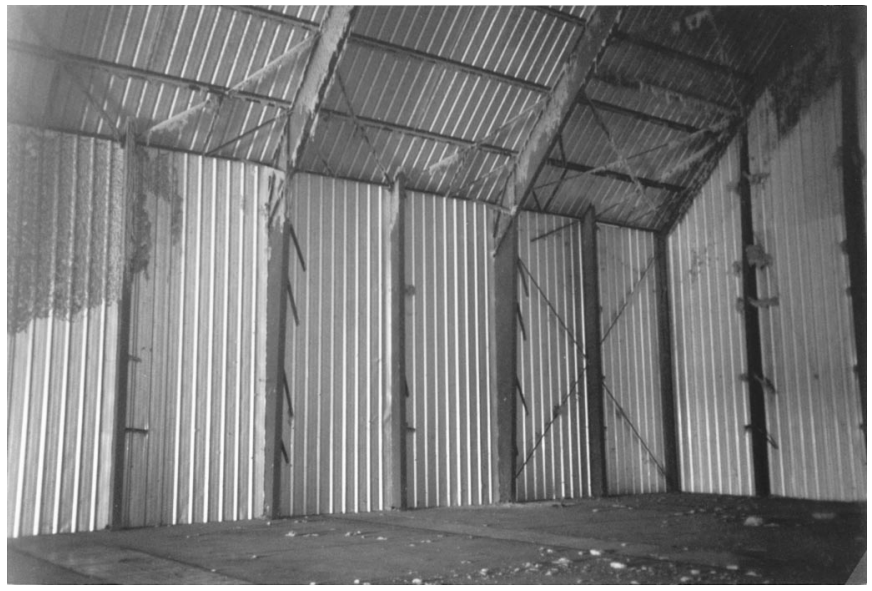

Fig. 2. Warehouse interior framing

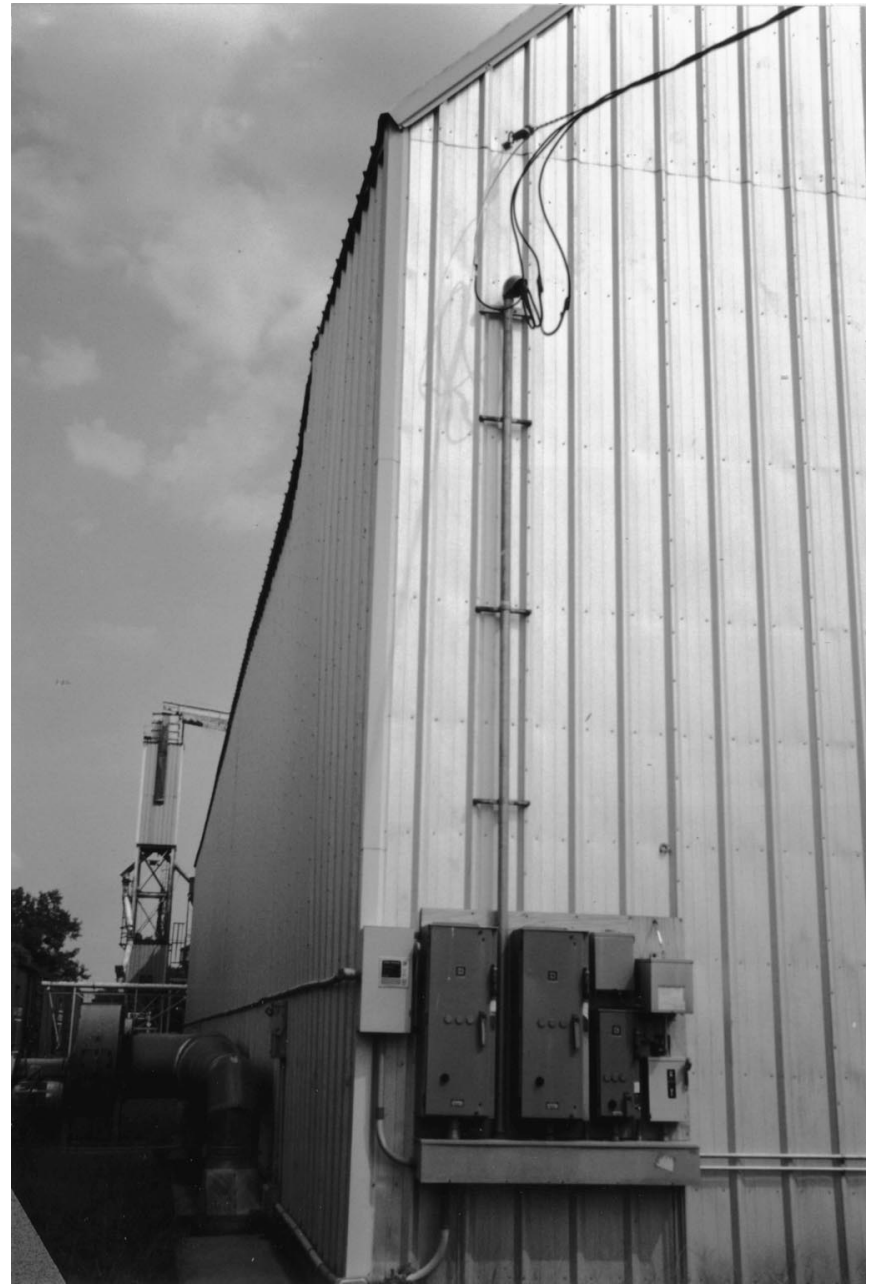

Fig. 3. Damage at eave line

5. As in warehouse 1, the greatest damage was closest to the end wall.

A second inspection was made in October 2000 to verify the previous observations. At this time, some seed was stored on the floor of warehouse 1, but the pile did not extend to the walls of the building. The damage was no worse, but the buildings had not been fully loaded with seed in the meantime. The need to keep the

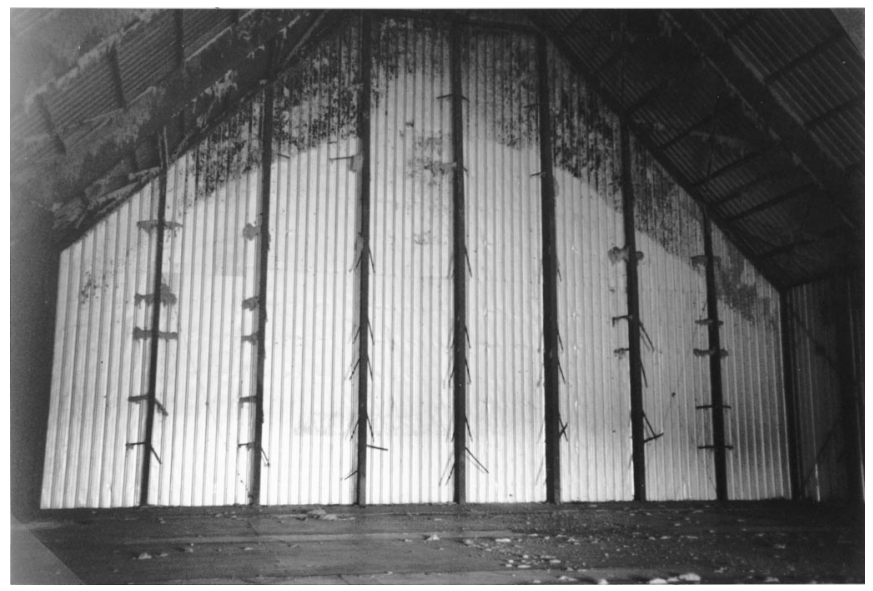

Fig. 4. Column flange braces torn away at end wall 


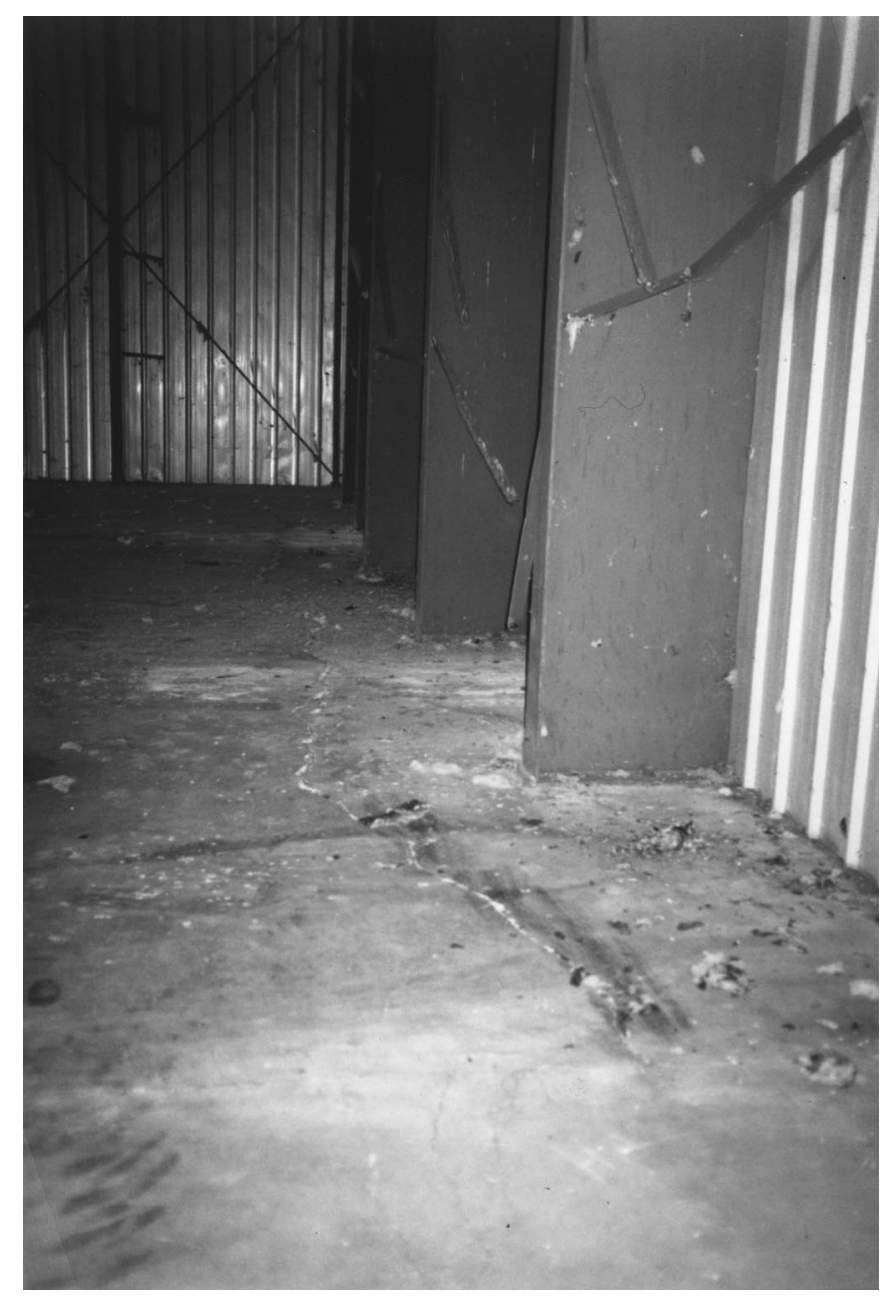

Fig. 5. Cracking near side wall columns

seed from piling up against the wall reduced the storage capacity of the warehouses to a small fraction of the designed capacity. Clearly, the buildings had failed and could not be used as intended without risk of further damage and possible collapse.

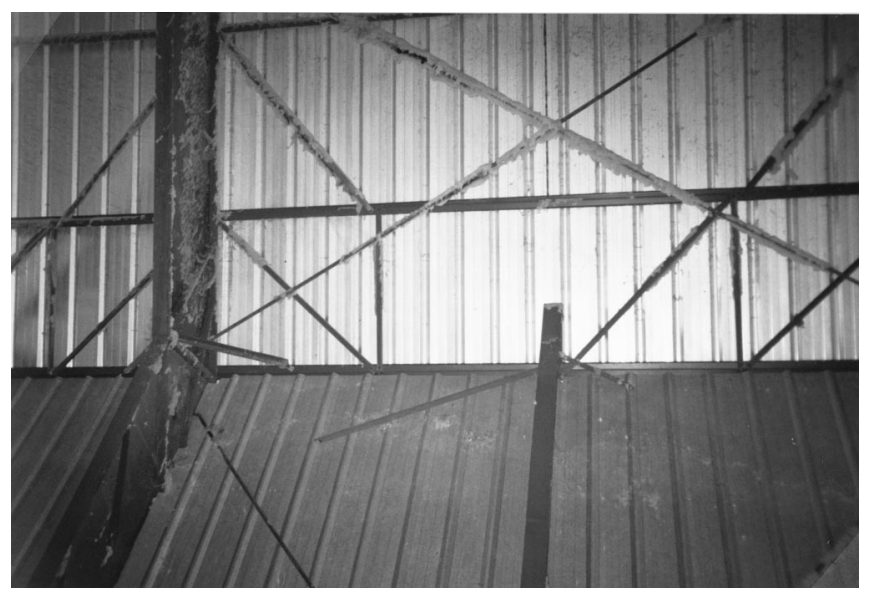

Fig. 6. Interior column brace torn, warehouse 2

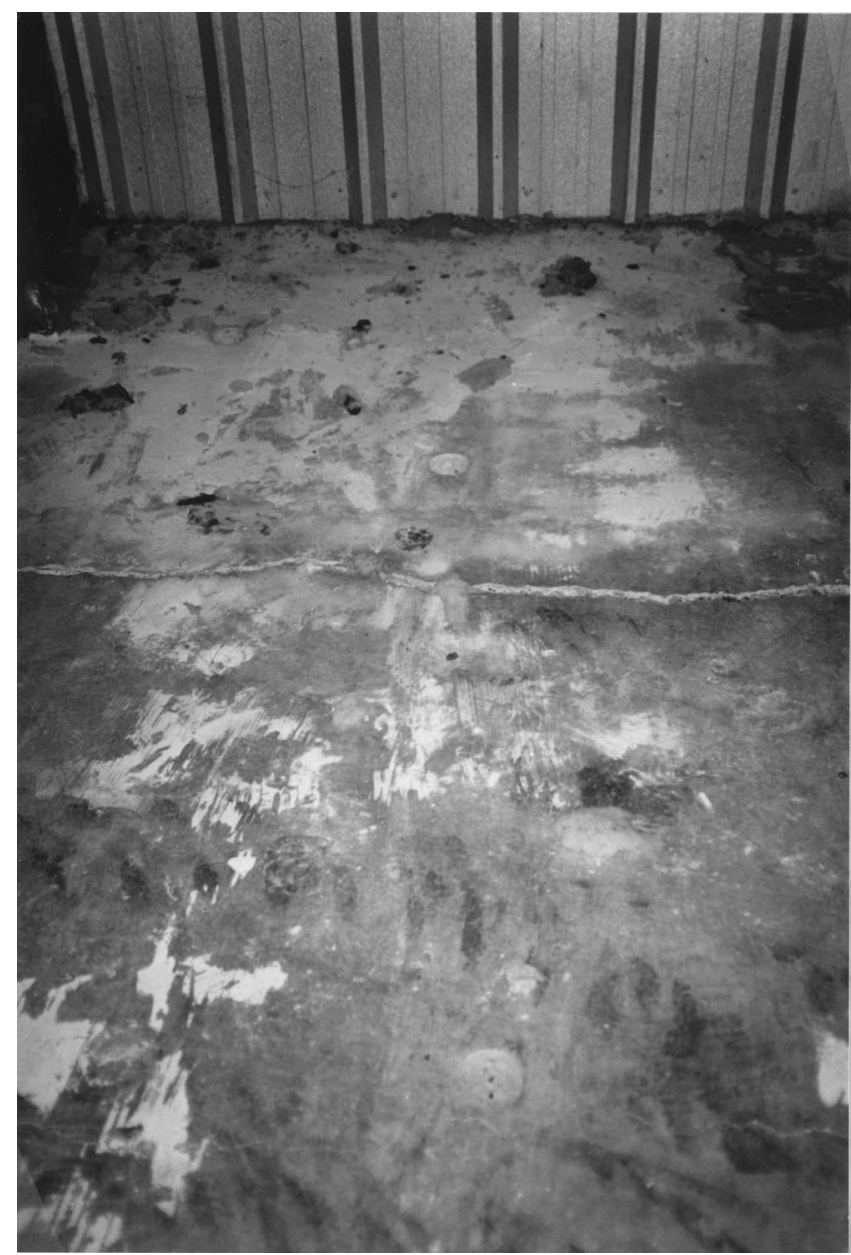

Fig. 7. Cracking near end wall, warehouse 2

\section{Review of Documents and Depositions}

Following the initial inspection, a number of documents and records were obtained and reviewed. Most of the project records and reports were available. The attorneys for the plaintiff and for the defendants obtained depositions from several dozen individuals. The most relevant documents included the metal building manufacturer's records, the soil testing report used for construction, the foundation design, depositions by the building erector's personnel, results of soil and concrete testing following the building failure, and a document providing information about the agricultural product loads.

\section{Warehouse Steel Structure Designer}

The metal building manufacturer's plans, shop drawings, and job file were available for review. The design had been carried out with computer software, following industry practices. The software used the direct stiffness method. The Metal Building Manufacturer's Association (MBMA) publishes a manual prescribing loads for this type of structure, such as a snow load of $240 \mathrm{~Pa}(5$ psf) and a wind load of $843 \mathrm{~Pa}$ (17.6 psf) based on a wind speed of $39.3 \mathrm{~m} / \mathrm{s}(88 \mathrm{mph}$ ) for the building location (MBMA 1996). These loads were shown in the computer program output in the job file.

However, this manual does not directly address the loads from agricultural products. These loads were very high, as much as 
6-12 times the wind pressure. Loads due to agricultural product were not reflected in the computer program output reviewed by the writer.

The agricultural product loads were shown on one sheet of the plans supplied to the erector and owner as horizontal reactions to be applied to the foundation slab. This sheet showed only force reactions and not moment reactions. A pinned base column is often assumed for design of low-rise metal buildings (e.g., Lee et al. 1981). Moment reactions occur at the base of a column when it is subjected to lateral loads (and acts as a beam-column), unless the column base is detailed to allow rotation. The impact of this assumption on the building performance is discussed below.

The steel structure plans were supplied without a foundation plan, except for an anchor bolt layout. In accordance with common industry practice, the plans contained a disclaimer stating that the building designer was not assuming liability for foundation, floor, or slab design or construction. The owner was told to hire a foundation designer and provide him with the plans.

\section{Soil Testing and Foundation Design}

The owner hired a soil testing firm (laboratory A) for site testing and compaction recommendations. The testing firm prepared recommendations and provided field density reports during construction. Some of the testing reports prepared during construction by this laboratory suggested higher soil moisture contents and lower densities than the recommendations, and it is unclear from the record whether these problems were corrected.

The owner asked the soil testing firm's licensed engineer to prepare a foundation plan. The drawing prepared by the testing firm engineer provided a layout with a specification for $27.6 \mathrm{MPa}$ (4,000 psi) concrete containing polypropylene fiber reinforcement (specified by a trade name). The slab was $125 \mathrm{~mm}$ (5 in.) thick with an outer turndown beam 406 by $406 \mathrm{~mm}$ (16 by 16 in.). A footing $1.07 \mathrm{~m}$ (42 in.) square was provided under each column.

Two $15.9 \mathrm{~mm}$ (5/8 in.) diameter steel reinforcing bars (designation $16 \mathrm{M}$, US \#5) were specified to be continuous around the perimeter of the foundation in the turndown beam, with additional bars of the same size in the footer. However, no reinforcing steel was specified in the interior of the slab to resist the outward horizontal reactions and moments at the column bases.

The foundation design cover letter stated that a soil support value of $120 \mathrm{kPa}(2,500 \mathrm{psf})$ had been used to develop the recommendations. This was assumed in the writer's analysis to be the ultimate bearing capacity of the soil.

\section{Building Erector}

Once the foundation was prepared, a construction firm was hired to erect the building. Adjustments had to be made during construction because the building was purchased with an interior liner, which was not shown on the plans supplied by the metal building manufacturer. The liner may be seen in Figs. 2 and 4.

The original detail for the flange braces showed them bolted to the purlins along the walls. However, with the interior liner in place, they could not be attached directly to the purlins. Therefore, the flange braces were attached with self-tapping screws installed through the liner panel into the purlins. Furthermore, some of the flange braces were field modified to fit by flame cutting or similar methods. In some cases, little metal was left for attachment.

\section{Testing Laboratory Results}

One of the defendants' attorneys hired a testing laboratory (laboratory B) to investigate the soil and concrete slab at each warehouse. This laboratory had not been previously associated with the project.

At warehouse 1, seven field density tests were performed. Densities varied from 89 to $98 \%$. Three of the seven tests were less than the $95 \%$ density required in laboratory A's recommendations. Four field density tests were performed at warehouse 2. Densities ranged from 83 to $93 \%$, and none met the specification prepared by laboratory A.

At warehouse 2, four concrete cores were removed. One of the cores, taken through the nominally $125 \mathrm{~mm}$ (5 in.) part of the slab, was only $111 \mathrm{~mm}$ (4 3/8 in.) long. The others were all taken around the perimeter beam. The short core suggests an inadequate thickness of the slab for at least one point, but it is not enough to form a conclusion.

Two cores were cut to make a total of five specimens for compression testing. Test results were 22.2, 24.1, 29.0, 29.4, and $31.9 \mathrm{MPa}(3,221,3,497,4,202,4,260$, and 4,622 psi). Three Windsor Probe tests were made on the foundation. The compressive strengths predicted using the Windsor Probe were 23.6, 32.8, and $34.3 \mathrm{MPa}(3,425,4,750$, and 4,975 psi).

\section{Agricultural Product Loads}

The owner provided the writer with a document that provided information about cottonseed loads. He stated that a copy of this document had been provided to the metal building designer and other parties. The document was undated, but listed a 1987 reference. He also provided a photograph of a warehouse in a neighboring state where the end wall had failed due to the outward pressure of the agricultural product, and stated that he had shown the photograph to the building designer and others.

According to the document on cottonseed loads, the bulk density of cottonseed is $400 \mathrm{~kg} / \mathrm{m}^{3}$ mass and $3.92 \mathrm{kN} / \mathrm{m}^{3}$ weight $(25$ $\left.\mathrm{lb} / \mathrm{ft}^{3}\right)$ and has an angle of repose $(\varphi)$ of $45^{\circ}$. The lateral wall pressure may be estimated using the following formula:

$$
W P=k \times D \times H
$$

where $W P=$ lateral wall pressure; $k=$ pressure coefficient $(0.20$, based on the angle of repose of $45^{\circ}$ and rounded up); $D$ = density; and $H=$ height or seed depth (Willcut et al. undated).

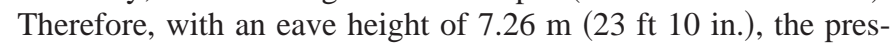
sure at the base of the wall was $5.75 \mathrm{kPa}\left(120 \mathrm{lb} / \mathrm{ft}^{2}\right)$. The pressure increases linearly from zero at the top of the wall to a maximum value at the bottom.

Therefore, the resultant of the pressure distribution is

$$
F=\frac{1}{2} \times k \times D \times H^{2} \times L
$$

where $F=$ resultant force; $L=$ length of wall between columns $(3.05 \mathrm{~m}$, or $10 \mathrm{ft})$; and other variables are as previously defined. The resultant force acts at $1 / 3 \mathrm{H}$ from the bottom of the wall.

Agricultural product may be analyzed as a cohesionless soil to determine lateral pressures. For a cohensionless soil, the active earth pressure coefficient $k$ is

$$
k=\tan ^{2}\left(45-\frac{\varphi}{2}\right)
$$

where $\varphi=45^{\circ}$, as noted earlier. This gives an active pressure coefficient of 0.172 , close to the value of 0.2 suggested by Willcut 
et al. (undated). Eqs. (1)-(3) are the commonly used Rankine formulas for active soil pressure, which may be obtained from a number of soil mechanics texts, such as Dunn et al. (1980).

Therefore, along the side walls, each column has an outward resultant force of $63.2 \mathrm{kN}(14,200 \mathrm{lbs})$ acting $2.42 \mathrm{~m}(8 \mathrm{ft})$ from the base of the wall. On the end walls, the outward resultant forces are as much as $303 \mathrm{kN}(68,000 \mathrm{lbs})$.

Since the building is loaded from one end, it is possible to have a full load of cottonseed on the far wall, with no load against the inside of the near wall (door end). This provides a total force of $1,670 \mathrm{kN}$ (375 kips) acting on the rear wall, at a location of $4.66 \mathrm{~m}(15.3 \mathrm{ft})$ from the base of the wall. In fact, this condition is not only possible but also unavoidable in the course of operating the warehouses as intended.

\section{Failure Hypotheses}

Five hypotheses were considered. These included steel structure design error, construction error, foundation design error, low strength concrete, or differential settlement. The possibility of an extreme loading such as hurricane wind loading, earthquake, or another similar event was considered but rejected, since there was no evidence that such an event had occurred since the buildings had been constructed. As mentioned above, the buildings were some distance apart, but exhibited nearly identical distresses. Combinations of causes were considered.

\section{Steel Structure Design Error}

Inadequate design of the steel structure by the metal building manufacturer was considered. Supporting evidence included structural damage that could not be readily attributed to the foundation failure. The suggested failure mechanism was the outward pressure imposed by the stored cottonseed.

\section{Construction Error}

The possibility that the erector made unauthorized changes during construction was considered. The main supporting evidence for this hypothesis was the flange brace installation that did not match the plans or the shop drawings. The suggested failure mechanism was also cottonseed pressure.

\section{Foundation Design Error}

Review of the documents suggested that the foundation design by the engineer employed by laboratory A violated the applicable American Concrete Institute (ACI 1995) design provisions and was inadequate to resist the building column reactions. Again, the failure mechanism would have been cottonseed pressure.

\section{Low-Strength Concrete}

The strength results noted from the core testing and Windsor Probe observed by laboratory B were used by some of the parties involved to suggest that the concrete delivered was of inadequate quality. Since the foundation loads should have been resisted by reinforcing steel to meet the code requirements, it was not clear to the writer how this would lead to the observed failure.

\section{Differential Settlement}

Another suggested contributing factor was the low soil compaction results, observed by laboratory $\mathrm{B}$ and also suggested by the laboratory A records, which could have led to differential settlement. However, since the critical forces applied were outward, and not against the soil, this did not seem as significant as the other factors considered. Furthermore, the maximum vertical loads of the building and stored cottonseed were about half the bearing capacity assumed by the foundation designer and soil test company (laboratory A).

\section{Analysis}

The writer analyzed the structure and foundation to determine which of the hypotheses were most likely. This included an analysis of the load path and a structural analysis to determine column forces and base moments, concrete slab foundation stresses, column flange brace forces, interior soldier column top brace forces, and overall stability against unbalanced cottonseed loading.

\section{Load Path}

As part of the structural analysis, it was necessary to determine the load path for the cottonseed lateral loads. The cottonseed pressed outward against the inner liner of the building. In turn, the purlins between the inner liner and the outer skin of the building carried the loads horizontally to the columns. The forces were transmitted from the purlins to the columns through girt clips and the flange braces. Finally, the forces were carried to the foundation through the columns.

\section{Steel Column Base Moments}

The writer performed a structural analysis to determine the actions of individual members on the foundation slab. The structural analysis computer program results provided by the metal building manufacturer indicated that the structural engineer modeled the columns as pinned at the base.

However, the pattern of damage suggested a prying action at the base of the most heavily loaded columns. The D-shaped cracks around some of the column bases, with cracks propagating through the edge turndown beam, provided strong evidence of this behavior. The column base plate detail, with bolts $305 \mathrm{~mm}$ (12 in.) apart, was sufficient to provide a fixed base connection. An expert witness for the metal building manufacturer suggested that the base plate connection was a hybrid hinge, but admitted that some moment would nevertheless be transmitted to the slab. Also, this witness did not perform an analysis of the structure, but had been asked only to evaluate the foundation. Therefore, he did not attempt to calculate the magnitude of the moments.

The intermediate soldier columns, the gable frame columns, and the end wall columns were analyzed in order to determine the force and moment reactions transmitted to the foundation slab. Braces at the top restrained the intermediate soldier columns.

Therefore, the amount of moment transmitted to the slab by the column base plate depends on the amount of displacement at the top of the column. The displacement under load was unknown, so two limiting cases were analyzed. The displacement would be between zero with full restraint against displacement at the top of the column, and $57.4 \mathrm{~mm}$ (2.26 in.) with no restraint. Since the actual amount of restraint provided by the top braces was difficult to determine, the two limiting cases of no and full restraint were analyzed in order to bracket the solution.

With those two limiting cases, the moment reaction applied to the foundation slab would be between 738 and 1,840 kN-m (544 and 1,360 in.-kips) for the full restraint and no restraint cases, 
respectively. The force reaction at the base of the column would be between $50.3 \mathrm{kN}(11,300 \mathrm{lbs})$ with full restraint and $63.2 \mathrm{kN}$ $(14,200 \mathrm{lbs})$ with no restraint. These reactions were determined using the force (or flexibility) method as described by Hibbeler (1990, 1991).

Frame analysis to determine the force reactions and moments at the base of the gable frame columns was complicated because the columns were tapered members. It is common in the metal building industry to use tapered members to improve economy (Lee et al. 1981; MBMA 1996). In this case, the gable frame column was $864 \mathrm{~mm}$ (34 in.) deep at the top and $533 \mathrm{~mm}$ (21 in.) deep at the base.

The gable frame column reactions were developed using the direct stiffness method as described by Hibbeler (1990), with modifications for tapered structural members determined by the Portland Cement Association (PCA 1958). The frame was assumed to be loaded symmetrically, with cottonseed pushing outward against both side walls simultaneously. The analysis predicted a force reaction of $29.8 \mathrm{kN}(6,710 \mathrm{lbs})$ and a moment reaction of $1,130 \mathrm{kN}-\mathrm{m}$ (831 in.-kips) at the column base.

End wall column reactions could be determined in the same way as the side wall intermediate soldier columns, because these columns were fixed at the base and restrained at the top-in this case, by the roof. However, since all of these columns were taller than the side wall columns, the force and moment reactions would be higher. Total force acting on the end wall is proportional to the column height squared, as indicated by Eq. (2), so for the tallest column at the ridge line the moment reaction would be at least 3,640 kN-m (2,600 in.-kips) and the force reaction would be at least $241 \mathrm{kN}(54,100 \mathrm{lbs})$, using the fully restrained case. If the flexibility of the connection at the roof were considered, the base reactions would increase.

For determining the effect of the column reactions on the concrete slab foundation, if the lowest force and moment reactions exceed the available material and structural capacity, it is not necessary to consider the larger forces. Therefore, the foundation was analyzed for a force reaction of $50.3 \mathrm{kN}(11,300 \mathrm{lbs})$ and a moment reaction of $738 \mathrm{kN}-\mathrm{m}$ (544 in.-kips).

\section{Concrete Slab Foundation}

The failure of the concrete slab could have been due to three factors:

- Inadequate concrete strength,

- Insufficient slab reinforcement, and/or

- High forces imparted to the foundation.

To evaluate whether inadequate concrete strength was a contributing factor, the core test strength results were compared with the ACI building code requirement. The code states in section 5.6.4.4 that core strength is adequate if the average of at least three cores is at least $85 \%$ of the required compressive strength, and every core is at least $75 \%$ of the required compressive strength (ACI 1995). The core test results reported exceeded these values. Therefore, there was no reason to suspect that the concrete delivered did not meet the job specification. Unfortunately, there was no record of any cylinders made or tested on this project.

Moreover, the critical stresses imposed on the foundation were tension imposed by column base forces and moments, not compression. No reinforcement was shown in the interior of the slab to resist these forces. The ACI building code states in section 10.2.5 that the tensile strength of concrete shall be neglected in axial and flexural calculations, and thus requires steel reinforcement to resist tensile forces (ACI 1995). The design clearly vio- lated the code. The polypropylene fibers can provide crack control, but do not meet the requirement for tension reinforcement.

As the last step in the analysis of the slab, the concrete tensile and flexural stresses imposed at the column bases were considered. For the $27.6 \mathrm{MPa}$ (4,000 psi) compressive strength specified, tensile and flexural strength would be approximately 4,500 $\mathrm{kPa}$ (650 psi) (Mindess and Young 1981). Using the lowest column force and moment reactions determined earlier, the concrete slab stress would be $7,500 \mathrm{kPa}(1,090 \mathrm{psi})$, well in excess of concrete strength. Therefore, the unreinforced concrete slab was cracked by the forces and moments imposed by the steel structure, bending outward from the pressure of the cottonseed.

Another foundation deficiency was that the $406 \mathrm{~mm}$ (16 in.) edge beam was not thick enough to provide the required $635 \mathrm{~mm}$ (25 in.) of embedment for the column anchor bolts. Since the anchor bolts did not pull out, this deficiency does not seem to have contributed to the failure. The expert witness retained by the metal building manufacturer testified that the foundation was also deficient in other respects.

\section{Column Flange Braces}

Review of the structural design documents indicated that the flange braces were intended to prevent lateral-torsional buckling of the columns. The analysis of the load path, discussed above, noted that the cottonseed forces were transferred to the columns through these braces as well as through the girt clips. The flange braces were more than twice as stiff as the girt clips, so they would take carry about $2 / 3$ of the tensile forces as the walls were pushed outward by the cottonseed.

Therefore, an analysis was performed to determine whether the flange brace damage was due to the cottonseed loading. The American Iron and Steel Institute (AISI 1996) provides tables that may be used to determine the shear and pullout strength of screws installed into cold-formed steel members. Capacities were determined for a pair of \#12 screws installed through the liner into a $1.9 \mathrm{~mm}(0.075 \mathrm{in}$.) thick cold-formed Z-section purlin. Assuming higher-grade steel (448 MPa or $65 \mathrm{ksi}$ ), each screw capacity was $11.6 \mathrm{kN}(2,610 \mathrm{lbs})$ in shear and $4 \mathrm{kN}(895 \mathrm{lbs})$ in pullout tension. The grade of steel was unknown.

The tensile forces in the lateral braces increased linearly from the top to the bottom of each column. The bottom flange attachments on the side walls and end walls were considerably overstressed. The lowest brace had an axial force of $24.5 \mathrm{kN}(5,500$ lbs) and transmitted shear and tensile forces to the screw of 17.3 $\mathrm{kN}(3,890 \mathrm{lbs})$ each. Both pullout tension and shear capacities are exceeded, without considering interaction. Use of lower strength screws would make this deficiency worse.

Therefore, the pattern of damage to the flange braces shown in Figs. 2 and 4 was most probably due the outward force of the cottonseed. Other damage mechanisms were suggested, such as downward drag of the cottonseed or impact by forklifts. The former would have imposed much smaller forces than the outward cottonseed pressure, and the latter seemed unlikely in view of the extent and pattern of the damage.

\section{Intermediate Soldier Column Top Brace}

In each warehouse, one of the interior columns nearest the end wall showed damage at the top. In warehouse 1, the top of a column was shown outward, as shown in Fig. 3. In warehouse 2, one of the braces holding in the top of a column was torn away (Fig. 6). Analysis using both the Allowable Stress Design (ASD) 
and Load and Resistance Factor Design (LRFD) provisions of the American Institute of Steel Construction (AISC 1986, 1989) indicated that the connections for the braces were inadequate. Each brace had a maximum force of $20.5 \mathrm{kN}(4,600 \mathrm{lbs})$, but the capacity at the slotted hole was only $9.3 \mathrm{kN}(2,090 \mathrm{lbs})$. In the metal building manufacturer's job file, a document entitled "Correction Warranty" was found for replacing the two-part brace with a single continuous member, with a larger steel cross section. This document suggested that at some point, the metal building manufacturer realized that this detail was deficient.

\section{Overall Stability}

The damage mechanisms discussed so far are local, leading to distress but perhaps not the overall collapse of the structure. However, differential cottonseed loading would lead to a major danger of collapse. Moreover, the method used to load the structure guaranteed differential loading. As the cottonseed is blown into the far end of the building, the pile extends at a $45^{\circ}$ angle. Thus, the far end wall becomes fully loaded before any cottonseed reaches the front end wall.

The total force resultant of $1,670 \mathrm{kN}$ (375 kips) was resisted by $\mathrm{x}$-bracing in the end bays of the side walls. The braces for the left side end bay may be seen in Fig. 2. A total of four sets of braces resisted the force, and braces in compression were neglected in the writer's analysis due to their slenderness.

Based on the AISC ASD provisions (AISC 1989), the required rod brace diameter would be $89 \mathrm{~mm}$ (3.55 in.) for $248 \mathrm{MPa}$ (36 ksi) steel and $73 \mathrm{~mm}$ (2.87 in.) for $379 \mathrm{MPa}(55 \mathrm{ksi})$ steel. The required brace diameter is much greater than that provided.

\section{Discussion}

On the basis of the analysis, the writer concluded that the steel structure design and the foundation design were both deficient. Construction errors and inadequate soil compaction seemed to have played little or no role in the failure.

Review of the metal building manufacturer's plan and job file indicated that the cottonseed forces were never accounted for in design, although they were listed on the table of reactions for foundation design. This was a serious omission, because the cottonseed forces were much higher than the forces considered in design, and represented the controlling load case. Under the cottonseed loads, a number of the metal building structural elements were overstressed and damaged, and the structure was in danger of overall collapse. Therefore, the steel structure design was inadequate.

The foundation design was also inadequate and violated the ACI building code. The registered engineer who designed the foundation slab had not previously designed a foundation. He also missed some of the force reaction notations on the steel structure plans. This engineer was clearly operating outside of his area of expertise-nearly all of his recent experience had been in the preparation of soil test reports and recommendations for laboratory A and its clients.

A contributing factor was the practice of splitting responsibility for the structure and the foundation between two engineers. Neither took responsibility for the overall project. The metal building manufacturer's engineer disavowed responsibility for the foundation and provided incomplete information on the column base reactions. The foundation engineer misinterpreted some of the notations that were provided. Because of the high outward pressures imposed by the cottonseed, careful coordination of building design and foundation design was needed to ensure satisfactory performance. A single engineer of record could have prevented this failure of communication. The only common contact between the two engineers was the building owner.

During the writer's original inspection, the owner led the writer through a fifty-year-old metal cottonseed storage warehouse near warehouse 1 . The difference between the older building and the newer buildings was striking. The structural members were much thicker, and thick steel cables anchored the walls to eyebolts embedded in the concrete foundation. Clearly, the outward forces imposed by the cottonseed had been considered in the design of the older building. This building had given decades of trouble-free service.

\section{Conclusions}

Stored agricultural products such as cottonseed or peanuts impose significant outward pressures on warehouse walls. These forces may be predicted using standard soil mechanics equations. As demonstrated above, calculating these pressures is straightforward.

Since at least three of these warehouses have failed in the same predictable manner, counting the building observed earlier by the building owner, it is clearly important for designers of future agricultural product warehouses to consider these forces in design. It is particularly important to considered overall structural stability under unbalanced product loads.

It is also necessary to make sure that the designer's assumptions about structural behavior are consistent with the detailing. The column base connections were fixed, but were modeled as if hinged. Either a fixed or hinged connection could have been used, and the structure could have performed properly with either detail—so long as the structure and foundation designs took the actual connection behavior into account. Instead, the moment that cracked the foundation slab was not accounted for by either the structural engineer or the foundation engineer.

The practice of splitting responsibility for a structure between a manufacturer's structural engineer (who may know nothing about the site conditions) and a local foundation engineer (who may know nothing about metal building design and behavior) presents a high risk of failure. It is particularly dangerous when loads of the magnitudes discussed in this paper are present. A single engineer of record is needed in order to avoid poor performance due to poor communication.

A few hours before leaving the office to testify in the case, the writer was informed that the case had been settled. The settlement was confidential, and the terms were not disclosed to the writer.

\section{Acknowledgments}

The writer is indebted to Warner Clark for the insights he provided into the behavior and performance of these structures. One of the anonymous paper reviewers also provided a suggested addition to the conclusions.

\section{References}

American Concrete Institute (ACI). (1995). Building code requirements for structural concrete (ACI-318-95) and commentary (ACI 318R-95), Farmington Hills, Mich. 
American Institute of Steel Construction (AISC). (1986). Manual of steel construction, load and resistance factor design, 1st Ed., Chicago.

American Institute of Steel Construction (AISC). (1989). Manual of steel construction, allowable stress design, 9th Ed., Chicago.

American Iron and Steel Institute (AISI). (1996). Cold-formed steel design manual, Milwaukee.

Dunn, I. S., Anderson, L. R., and Kiefer, F. W. (1980). Fundamentals of geotechnical analysis, Wiley, New York.

Hibbeler, R. C. (1990). Structural analysis, 2nd Ed., Macmillan, New York.

Hibbeler, R. C. (1991). Mechanics of materials, 3rd Ed., Prentice-Hall,
Upper Saddle River, N.J.

Lee, G. C., Ketter, R. L., and Hsu, T. L. (1981). The design of single story rigid frames, Metal Building Manufacturer's Association, Cleveland.

Metal Building Manufacturer's Association (MBMA). (1996). Low rise building systems manual, Cleveland.

Mindess, S., and Young, J. F. (1981). Concrete, Prentice-Hall, Englewood Cliffs, N.J.

Portland Cement Association (PCA). (1958). Handbook of frame constants, Skokie, Ill.

Willcut, H. M., Mayfield, W. D., and Valco, T. D. (undated). Cottonseed storage, Cotton Incorporated, Raleigh, N.C. 